\title{
The Role of Diffusion-Weighted Imaging and Apparent Diffusion Coefficient Maps in Characterization of Solid Renal Lesions
}

\author{
Solid Renal Lezyonların Karakterizasyonunda Difüzyon Ağırlıklı Görüntüleme ve \\ Görünen Difüzyon Katsayısı Haritalarının Rolü
}

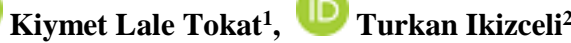 \\ 1- University of Health Sciences Bakirkoy Training and Research Hospital, Department of Radiology, Istanbul, Turkey. 2- University of Health \\ Sciences Haseki Training and Research Hospital, Department of Radiology, Istanbul, Turkey.
}

\begin{abstract}
Objectives: The purpose of this study was to evaluate the added value of Diffusion-Weighted Imaging (DWI) and Apparent Diffusion Coefficient (ADC) in distinguishing between benign from malignant solid renal lesions.

Material and Method: A total of forty-seven patients (age range: 33-84, mean: 59.0 11.3 years, 27 men, 20 women) with solid renal lesions detected on abdominal MR were included in our study group. The ADCs were calculated from DWI data of two different $b$ values ( $b=600 \mathrm{~mm}^{2} / \mathrm{s}$ and $b=1000 \mathrm{~mm}^{2} / \mathrm{s}$ ). ADC values for both normal renal parenchyma and solid renal lesions were obtained. Subsequently, ROI analysis was performed to identify threshold ADCs. In all cases, the histopathological data were obtained and correlated.

Results: The histopathological outcome comprises 13 benign and 34 malignant solid renal lesions. The solid malignant lesions were Renal Cell Carcinoma subtypes (1 chromophobe cell, four papillary cells, 25 clear cells), 2 Transitional Cell carcinomas, one metastasis, 1 Non-Hodgkin lymphoma. The benign solid renal lesions consisted of 2 oncocytomas and 11 angiomyolipomas. The mean ADC value of malignant lesions was 1,33 x 10-3 $\mathrm{mm}^{2} / \mathrm{s}$, benign masses for oncocytomas 1,76 x 10-3 mm²/s, and angiolipomas 1,28 x 10-3 mm²/s respectively $(p<0.001)$. The mean ADC value of normal renal parenchyma was $2,22 \times 10-3 \mathrm{~mm}^{2} / \mathrm{s}$, and the mean ADC value of benign and malignant masses without discrimination was $1.34 \times 10-3 \mathrm{~mm}^{2} / \mathrm{s}(p<0.001)$

Conclusion: $A D C$ values can be a useful parameter to differentiate malignant solid renal lesions in renal masses. Also, significant differences in $A D C$ values among $R C C$ subtypes indicate the availability of $A D C$ in $R C C$ subtype determination.

ÖZET

Amaç: Bu çalıșmanın amacı, benign ve malign solid renal lezyonları ayırt etmede Difüzyon Ağırlıklı Görüntüleme $(D A G)$ ve Görünen Difüzyon Katsayısı $(A D C)$ ile değerlendirmektir.

Gereç ve Yöntem: Abdomen MR'da solid renal lezyon saptanan toplam 47 hasta (yas aralığl: 33-84, ort: $59.0 \pm$ $11.3 \mathrm{yll}, 27$ erkek, $20 \mathrm{kadın})$ çalıșma grubumuza dahil edildi. ADC'ler, iki farklı b değerinin $\left(b=600 \mathrm{~mm}^{2} / \mathrm{s}\right.$ ve $b=$ $1000 \mathrm{~mm}^{2} / \mathrm{s}$ ) DAG verilerinden hesaplanmıştır. Hem normal renal parankim hem de solid renal lezyonlar için ADC değerleri elde edildi. Daha sonra, eșik ADC'lerini belirlemek için ROI analizi gerçekleștirildi. Tüm olguların histopatolojik verileri elde edildi.

Bulgular: Histopatolojik olarak 13 benign ve 34 malign solid renal lezyondan malign lezyonlar, Renal Hücreli Karsinom alt tipleri (1 kromofob hücre, dört papiller hücre, 25 berrak hücre), 2 Geçiş Hücreli karsinom, bir metastaz, 1 Non-Hodgkin lenfomadır. Lyi huylu solid böbrek lezyonları 2 onkositom ve 11 anjiyomiyolipomdan olusuyordu. Malign lezyonların ortalama ADC değeri sırasıyla 1,33 x 10-3 mm² / s, onkositomlar için 1,76 × 10-3 $\mathrm{mm}^{2}$ / s ve anjiyolipomlar $1,28 \times 10-3 \mathrm{~mm}^{2} / \mathrm{s}$ idi $(p<0,001)$. Normal renal parankimin ortalama ADC değeri 2,22 $\times 10-3 \mathrm{~mm}^{2} / \mathrm{s}$, benign ve malign kitlelerin ayrım yapılmaksızın ortalama ADC değeri $1,34 \times 10-3 \mathrm{~mm}^{2} / \mathrm{s}$ idi $(p$ $<0,001)$

Sonuç: ADC değerleri, solid renal kitlelerde malign-benign lezyonları ayırt etmede faydalı bir parametre olabilir Ek olarak, RCC alt tipleri arasında ADC değerlerindeki önemli farklllıklar, ADC'nin RCC alt tip belirlemesinde kullanılabilirliğini gösterir.
\end{abstract}

\section{INTRODUCTION}

The incidence of renal tumors is increasing, mainly due to the widespread use of cross-sectional imaging. A solid tumor observed in the kidney is considered renal cell carcinoma until proven otherwise, and it requires further examination (1). For the preoperative diagnostic evaluation of patients with renal masses, Computed Tomography and Magnetic Resonance Imaging (MRI) should be performed, according to uniform standards, for local staging and resection planning. Both imaging methods require the use of contrast agents (2). The contrast enhancement features of some tumors vary considerably since they have a solid, cystic, or necrotic area. With conventional MRI sequences, some malign masses can mimic benign, complex renal cysts $(3,4)$. The core-needle biopsy was not recommended for preoperative diagnosis of renal masses requiring surgical treatment until recently due to the belief that it would cause tumor transplantation and because of possible risks. Although biopsy has become widespread in the last 15 years, cystic componenttumors still cannot be biopsied. For these reasons, most renal masses are diagnosed postoperatively. Meanwhile, some benign tumors are operated on

Correspondence: Turkan Ikizceli, University of Health Sciences Haseki Training and Research Hospital, Department of Radiology. Adnan Adivar Street, Number:9, 34130, Fatih, Istanbul/TURKEY. Email: turkan.ikizceli@sbu.edu.tr

Cite this article as: Tokat KL, Ikizceli T. The Role of Diffusion-Weighted Imaging and Apparent Diffusion Coefficient Maps in Characterization of Solid Renal Lesions. Phnx Med J. 2020;2(3):138-144. 


\section{Tokat et al.}

unnecessarily due to their malignant appearance (5-7).

Many studies have shown that with newly developed MRI sequences, preoperative diagnosis is possible in renal masses. With MRI, tissues are differentiated from each other based on the $\mathrm{T} 1$ and $\mathrm{T} 2$ baseline signal characteristics. Diffusion-Weighted Imaging (DWI), used as an addition to conventional sequences, shows the molecular diffusion in biological tissues noninvasively. Images are obtained at short shooting times and without the need for contrast media (8). The apparent diffusion coefficient (ADC) map shows the absolute numerical value of the diffusion size measured over the $b$ value. It is used instead of the diffusion coefficient in biological structures. The "b value" is the diffusion sensitivity value and determines the strength and duration of the diffusion gradients. Many malignant tumors have diffusion reduction due to perfusion and increased nuclear macromolecules (9).

In this study, we obtained the ADC values of the renal masses obtained with DWI and the ADC values of healthy kidney tissue. This study aimed to investigate the usefulness of these values in the differentiation of benign-malignant masses, whether ADC values detected in malignancies would provide information about the nature of malignant masses and thus the contribution of DWI and ADC values to standard protocols.

\section{MATERIAL AND METHOD}

A total of 102 cases who were admitted to our Radiology Clinic in XX Hospital between March 2011 and March 2012 with early diagnosis of focal kidney mass in sonographic or abdominal tomography were evaluated. The study was approved by the Ethics Committee of Haseki Training and Research Hospital (with the decision no. 22.05.2009/24) and conducted prospectively. Informed consent forms were obtained from all cases.

In our study, a total of 47 cases with ages ranging from 33-84 years (mean age: $59.0 \pm 11.3$ years), 27 males and 20 females, were included. Eleven cases were clinically and radiologically followed-up with a diagnosis of angiomyolipoma for five years and were accepted as benign. The other 36 cases were diagnosed postoperatively. Cases with a lesion size of less than 1 $\mathrm{cm}$, history of renal cortical cysts or contrast agent allergy, significant artifact MR images, and those whose ADC values cannot be measured, those with MRI phobia and 55 patients who could not tolerate the examination were excluded from the study.

MRI protocol and parameters: 1.5 Tesla MR (Philips, Achieva, The Netherlands) was used in the study.

In the axial plane, T1A TSE (TE 7msn, TR 497msn, Flip 90, TSE factor 4, FOV 400, matrix 512, section thickness $8 \mathrm{~mm}$, gap $2 \mathrm{~mm}$, NEX 2, duration $75 \mathrm{~s}$ ), TSA TSE (TE 130, TR 555, Flip 90, TSE, FOV 400mm, matrix 512, slice $8 \mathrm{~mm}$, gap $2 \mathrm{~mm}$, NEX 2, duration 13 s), T2A TSE SPAIR (TE 130, TR 555, Flip 90, TSE, FOV $400 \mathrm{~mm}$, matrix 512, slice $8 \mathrm{~mm}$, gap 2mm, NEX 2, duration $13 \mathrm{~s}$ ); in the coronal plane, T2A TSE (TE 120, TR 486, Flip 90, FOV 400 mm, slice 8 mm, gap $2 \mathrm{~mm}$, NEX 2, duration holding the breath for $11 \mathrm{~s})$.

Before the contrast agent injection, first, the DWI single-shot EPI (TE 70 msn, TR 2500 msn, Flip 90, FOV 400, matrix 512, section thickness $8 \mathrm{~mm}$, gap 2 mm, NEX 2, duration $75 \mathrm{~s}$ ), images withheld breath and images at three different $b$ values (b:0-500-1000 $\mathrm{mm}^{2} / \mathrm{s}$ ) were obtained. ADC maps were created automatically on Workstation.

After the application of the contrast agent (gadopentetate dimeglumine, $0.1 \mathrm{mmol} / \mathrm{kg}$ ) by bolus injection for $30 \mathrm{~s}, 60 \mathrm{~s}, 120 \mathrm{~s}$, and $5 \mathrm{~min}$, T1A (TSE TE 7msn, TR 787 msn, Flip 90, TSE factor 4, FOV 400, matrix 384, section thickness $8 \mathrm{~mm}$, gap $2 \mathrm{~mm}$, NEX 2, duration $93 \mathrm{~s}$ ) images at the axial plane were added.

Table 1. Distribution of Renal Lesions.

\begin{tabular}{lccc}
\hline & $\begin{array}{c}\text { Benign } \\
\text { (n) }\end{array}$ & $\begin{array}{c}\text { Malign } \\
(\mathrm{n})\end{array}$ & Total \\
\hline Renal cell carcinoma & & & \\
$\quad$ Chromophobe & & 1 & $\mathbf{3 0}$ \\
$\quad$ Papillary cell & & 4 & \\
$\quad$ Clear cell & - & 25 & \\
Transitional cell carcinoma & - & 2 & $\mathbf{2}$ \\
Metastasis & - & 1 & $\mathbf{1}$ \\
Lymphoma & - & 1 & $\mathbf{1}$ \\
Oncocytoma & 2 & - & $\mathbf{2}$ \\
Angiomyolipoma & 11 & - & $\mathbf{1 1}$ \\
Total & $\mathbf{1 3}$ & $\mathbf{3 4}$ & $\mathbf{4 7}$ \\
\hline
\end{tabular}

Table 2: ADC difference in mass and healthy tissue $\left(\times 10^{-3}\right)$

\begin{tabular}{lcc}
\hline $\mathbf{n}=\mathbf{4 7}$ & Mean & Std. Deviation \\
\hline Mass ADC & 1.34 & 0.27 \\
\hline Normal ADC & 2.22 & 0.28 \\
\hline Difference & 0.88 & 0.30 \\
\hline & $\mathrm{t}=19.86$ & $\mathrm{p}<0.001$
\end{tabular}

Image analysis: Images obtained from 47 patients were analyzed in DICOM format on PACS-compliant workstations, and automatic ADC maps were generated. T1A, T2A, oil buffer T2A images, and DWI and ADC maps were evaluated in terms of the signal intensity of the lesions. ADC values were measured separately by placing ROIs in kidney mass area that was contrast absorbance, DWI hyperintense, and 
showing hypointense diffusion limitation at ADC images and in normal renal parenchyma. The ADC value was calculated manually by placing an ROI in the tumor. The ROI was chosen to include solid components of the tumor and was set as large as possible. However, the necrotic part, which was suggested from T1 and T2 weighted images, was not included in the ROI if possible. Means of the masses with sizes above $3 \mathrm{~cm}$ were calculated by measuring the ADC at three various locations. In lesions with heterogeneous internal structures, conventional sequences, and contrast-enhanced sections, measurements were made from the contrast-absorbent solid parts.

DWI was obtained in values $b=0 \mathrm{~mm}^{2} / \mathrm{s}, \mathrm{b}=600 \mathrm{~mm}^{2} / \mathrm{s}$, and $b=1000 \mathrm{~mm}^{2} / \mathrm{s}$. In statistical analysis, however, only the $b=1000$ value where the diffusion effect was the highest was used.

Statistical Analysis: The comparisons of quantitative data between two groups were made by Student's t-test, and the comparisons between the three groups were made by one-way ANOVA and Tukey had multiple comparison methods. Inter-group correlations were evaluated by paired t-test. The distribution of categorical characteristics was compared with the Chisquared test. The statistical significance limit was accepted as $\mathrm{p} \leq 0.05$.

\section{RESULTS}

Of 47 patients with detected renal mass, 30 had renal cell carcinomas, two transitional cell carcinomas, one metastasis, one lymphoma, two oncocytomas and 11 had angiomyolipomas diagnosis (Table 1).

The mass sizes were between $12-128 \mathrm{~mm}$, and the mean was $52.81 \pm 26.71 \mathrm{~mm}$.

The mean average renal parenchyma ADC values were determined as $2.22 \times 10^{-3} \mathrm{~mm}^{2} / \mathrm{s}$. The mean ADC value of the masses was $1.34 \times 10^{-3} \mathrm{~mm}^{2} / \mathrm{s}$ without benignmalignant distinction. The mean ADC value obtained from the masses was significantly lower than the mean normal kidney parenchyma ADC value $(\mathrm{p}<0.001)$ (Table 2).

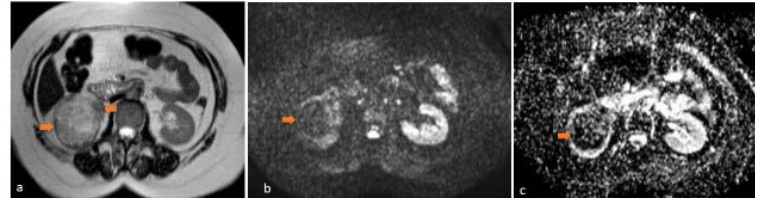

Figure 1: A 62-year-old male patient. Solid mass (clear cell subtype) containing $55 \times 70 \mathrm{~mm}$ cystic areas (blue arrow) in the right kidney middle zone a) A hypointense heterogeneous mass containing cystic necrotic areas in T2-WI b) DWI restriction in solid components of the mass c) Mass solid component ADC value in $\mathrm{ADC}$ map 2,306x10-3 mm²/s, normal kidney parenchyma ADC value is measured as $3,188 \times 10-3 \mathrm{~mm}^{2} / \mathrm{s}$.

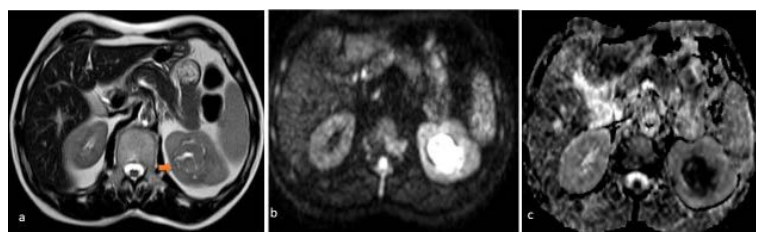

Figure 2: A 66-year-old male patient. An exophytic localized, well-circumscribed mass (papillary cell subtype) in the left kidney. a) A heterogeneous hypointense solid mass in the left kidney in T2-WI section b) DWI restriction in the mass c) ADC value in the ADC map is measured as $1.097 \times 10-3 \mathrm{~mm}^{2} / \mathrm{s}$, ADC value in the normal kidney parenchyma is measured as $2,150 \times 10-3 \mathrm{~mm}^{2} / \mathrm{s}$.

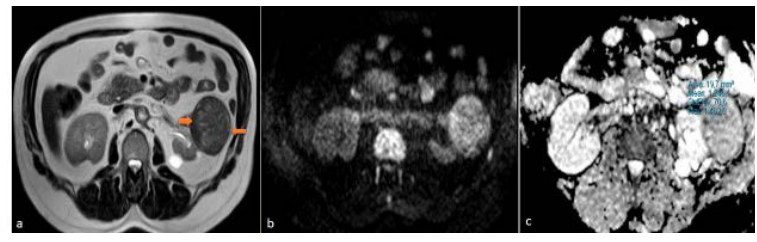

Figure 3: A 51-year-old male patient. 31x38mm lobulated mass in the left kidney pelvis (Transitional cell carcinoma) a) A heterogeneous hypointense mass originating from the left kidney in T2-WI b) DWI shows marked diffusion restriction in the mass c) $\mathrm{ADC}$ value is $1.127 \times 10-3 \mathrm{~mm}^{2} / \mathrm{s}$ and normal kidney parenchyma ADC value is measured at $2.063 \times 10-3 \mathrm{~mm}^{2} / \mathrm{s}$.

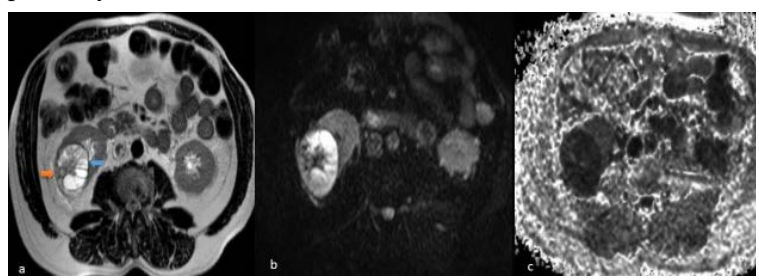

Figure 4: A 65-year-old female patient. a) In the right kidney upper pole, a $58 \times 60 \mathrm{~mm}$ sized solid limited solid mass (Angiomyolipoma) in T2-WI b) DWI in diffuse restriction in the mass c) ADC value in the ADC map $1.118 \times 10-3 \mathrm{~mm}^{2} / \mathrm{s}$ and normal kidney parenchyma $\mathrm{ADC}$ value are measured at $2.368 \times 10$ $3 \mathrm{~mm}^{2} / \mathrm{s}$.

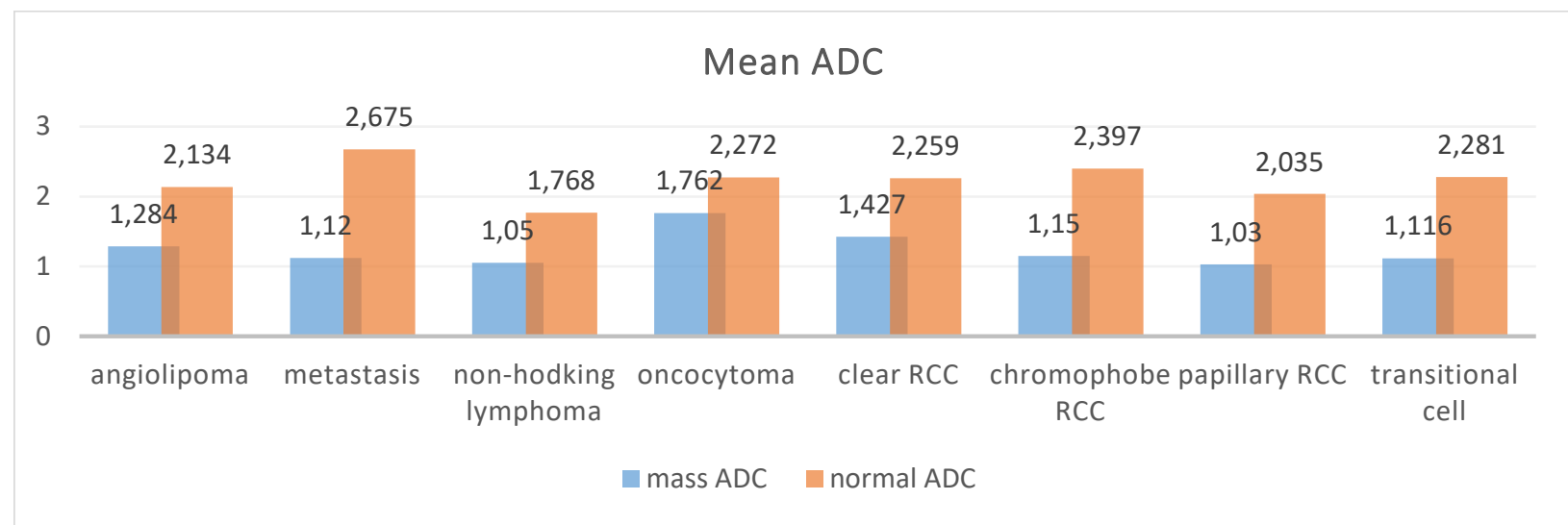

Graphic 1: The difference between mass ADC and normal ADC according to pathological diagnosis 
Tokat et al.

Table 3: Mass and normal tissue ADC, mass-normal ADC ratio of the malignant-benign groups

\begin{tabular}{lcccccc}
\hline & & $\mathbf{n}$ & Mean & SD & T & p \\
\hline Mass ADC x 10 & malign & 34 & 1.33 & 0.26 & -0.267 & 0.791 \\
& benign & 13 & 1.36 & 0.31 & & \\
Normal renal ADC x 10 1 $^{-3}$ & malign & 34 & 2.24 & 0.28 & 0.933 & 0.356 \\
& benign & 13 & 2.16 & 0.26 & & \\
ADC mass - normal tissue & malign & 34 & 0.91 & 0.33 & 1.101 & 0.277 \\
difference x 10 & benign & 13 & 0.80 & 0.21 & & \\
\hline
\end{tabular}

SD: Standart Deviation

Table 4: RCC clear cell and papillary subtype, angiomyolipoma, mass ADC, normal ADC, and their differences.

\begin{tabular}{l|lccccc}
\hline \multicolumn{2}{l}{ Mass ADC } & n & mean & SD & f & p \\
& RCC Papillary & 4 & 1.03 & 0.35 & 5.105 & 0.001 \\
& RCC Clear & 25 & 1.43 & 0.21 & & \\
Normal ADC & Angiomyolipoma & 11 & 1.28 & 0.28 & & 0.256 \\
& RCC Papillary & 4 & 2.07 & 0.37 & 1.413 & 0.25 \\
Mass/Normal & RCC Clear & 25 & 2.26 & & 0.406 \\
difference & Angiomyolipoma & 11 & 2.13 & 0.28 & & \\
ADC & RCC Papillary & 4 & -1.04 & 0.17 & 0.923 & \\
\end{tabular}

SD: Standart Deviation

RCC subtypes mean ADC values were compared. The mean ADC value of the clear cell subtype was determined as $1.43 \pm 0.21 \times 10^{-3} \mathrm{~mm}^{2} / \mathrm{s}$ (Figure 1 ). The mean ADC value of the papillary subtype was determined as $1.03 \pm 0.35 \times 10^{-3} \mathrm{~mm}^{2} / \mathrm{s}$ (Figure 2). The mean ADC value of the clear cell subtype was significantly higher than the mean ADC value of the papillary subtype $(p<0.001)$ (Table 3$)$. Significant diffusion limitation and low ADC values were obtained in transitional cell RCC (Figure 3), metastasis, and non-Hodgkin lymphoma (Graphic 1).

The mean ADC value of the malignant masses was determined as $1.33 \times 10^{-3} \mathrm{~mm}^{2} / \mathrm{s}$. The mean ADC values of the benign masses were determined as $1.76 \times 10^{-3}$ $\mathrm{mm}^{2} / \mathrm{s}$ for oncocytoma and $1.28 \pm 0.28 \times 10^{-3} \mathrm{~mm}^{2} / \mathrm{s}$ for angiomyolipoma. When the malignant mass ADC values were compared with benign mass oncocytoma ADC values, malignant mass ADC values were found to be statistically significantly lower $(\mathrm{p}<0.001)$. Although angiomyolipomas $(n=11)$ were benign, they were found to show low ADC values at $1.28 \pm 0.28 \times 10^{-}$ ${ }^{3} \mathrm{~mm}^{2} / \mathrm{s}$ as malignant masses (Figure 4) (Table 4).

\section{DISCUSSION}

Since the end of the 1990s, DWI has found its place in the diagnostic applications of abdominal examinations. Although obtaining DWI in abdominal examinations is still a problem due to artifacts due to bowel movements, its use in the diagnostic field is increasing $(10,11)$. With the development of the Ultrafast EPI sequences, the shooting time was achieved in such a brief time as 30-60 sec, and the artifacts caused by respiratory, vascular, and bowel movements decreased (10). The diffusion coefficient, based on movement at the molecular level, is under the influence of the intracellular organelles, macromolecules, membranes, viscosity, environmental temperature, vascular perfusion, and the magnetic susceptibility of tissues. For this reason, instead of the diffusion coefficient, ADC maps calculated over the "b" value can be used. The "b value" is the diffusion sensitivity value and determines the strength and duration of the diffusion gradients (12). As the b value increases, the diffusion weight also increases, and the T2 signal effect decreases (13). The most critical parameters that determine ADC in tissue are water diffusion and microcirculation (9). The kidney is very suitable for diffusion studies with hypomotility of water molecules in the parenchyma and high blood flow (14). While there is no clear consensus on which $b$ value to use in the evaluation of renal lesions in the literature, the recommended value of $b$ is between 600 and 1000 $\mathrm{s} / \mathrm{mm}^{2}$ (15). In our study, we used a high "b value" ( $b=1000 \mathrm{~mm}^{2} / \mathrm{s}$ ) to decrease the perfusion effect and increase diffusion efficiency. In studies using different 
b values in the literature, it was seen that ADC values proportionally reduced in the same lesion as the $b$ value increased $(16,17)$. Zhang et al. noted that there were more standard deviations in ADC measurements when lower $\mathrm{b}$ values were used. It is emphasized that high $\mathrm{b}$ values increase ADC accuracy $(18,19)$. Because the perfusion effect will be more significant at lower b values, the ADC values may be higher than expected. Similarly, since capillary microcirculation increases in malignant masses, we thought that $a$ high $b$ value would be more beneficial. Another advantage of the high $b$ value is that the examination time is short (20).

There is a good relationship between ADC values and the glomerular filtration rate (21). It has been stated that DWI and ADC can non-invasively show microstructural changes in the early period of fibrosis in parenchymal renal diseases. Also, there are studies using ADC values in treatment follow-up $(22,23)$. In our study, we compared the mass ADC values of the cases with their parenchyma ADC values. In this way, for the assessment of individual glomerular function, the connection between one's parenchyma and mass ADC measurements can be better understood. Mass ADC values were $1.34 \pm 0.27 \times 10^{-3} \mathrm{~mm}^{2} / \mathrm{s}$, while parenchymal ADC values were $2.22 \pm 0.28 \times 10^{-3} \mathrm{~mm}^{2} / \mathrm{s}$ and there was a statistically significant difference between them $(p<0.001)$. It can be concluded that the increase in diffusion sensitivity is due to the absence of parenchymal disease among the cases and the high $b$ value. In the literature, quite different results have been reported between ADC values of the renal medulla and renal cortex. It is stated that the reason for this may be the use of different b values. Wang et al. described diffusion differences between normal renal parenchyma and RCC subtypes. Normal renal parenchyma ADC was found as $2.30 \pm 0.17 \times 10^{-3} \mathrm{~mm}^{2} / \mathrm{s}$ and was similar to the findings in our study (24).

Since diffusion in DWI in dense cells that are an indicator of tumor aggressiveness will be limited, ADC will also below $(25,26)$. Although it has been reported that there may be a biological marker that predicts ADC tissue cellularity, there are also quite different results in the literature. It is stated that there may be a medium biomarker for renal cell tumors (27). In the study conducted by Wang et al. ( $b=800)$, the clear cell RCC mean ADC value was found to be $1.698 \times 10^{-}$ ${ }^{3} \mathrm{~mm}^{2} / \mathrm{s}$, and a significant difference was observed between the other RCC subtypes (24). Similarly, Taouli et al. reported that RCCs might be useful in subtype determination when DWI is added to contrastenhanced dynamic MRI. They obtained the lowest ADC in papillary carcinoma (28). In our study, we found the clear cell RCC ADC as $1.43 \pm 0.21 \times 10^{-3} \mathrm{~mm}^{2} / \mathrm{s}$ and the mean ADC value of papillary type RCC as $1.03 \pm 0.35 \times 10^{-3} \mathrm{~mm}^{2} / \mathrm{s}$. The fact that the mean clear cell RCC ADC value was higher than the mean papillary type RCC ADC value changed ADC values due to intra-mass cellularity, vascularity, and the nature of the mass. Rosenkranz et al. described the differences in ADC values between low nuclear grades and high nuclear grades of clear cell RCCs. High-grade clear cell RCC ADC was found to be lower than low-grade clear cell RCC ADC (29). This showed that ADC could also be used to determine the nuclear grade of preoperative RCC subtypes. Since the number of chromophobe cell cases included in our study was 1, it could not be included in the statistical evaluation. Again, in our research, one lymphoma, one metastasis, and one transitional cell tumors had high cellularity due to their nature, and the ADC values in these were found to be low by the literature.

Studies have shown that the mean ADC value-of benign lesions is higher than the mean ADC of malignant lesions. Similarly, the mean ADC value of benign cysts was found to be higher than the mean ADC value of malignant cystic lesions (30). Similarly, Razek et al. found a significant difference between ADC values of malignant and benign masses and found the mean ADC value of angiomyolipoma's $(b=1000)$ as $1.07 \pm 0.47 \times 10^{-3} \mathrm{~mm}^{2} / \mathrm{s}$, as with malignant lesions. They emphasized that this was the result of diffusion restriction due to high-fat content (31). Similarly, in our study, mean ADC values of cases with angiomyolipoma $(n=11)$ were found to be low $\left(1.28 \pm 0.28 \times 10^{-3} \mathrm{~mm}^{2} / \mathrm{s}\right)$. In future studies, angiomyolipomas should be categorized separately in more extensive series with more cases. In this way, ADC studies for benign masses will show ADC values more objectively.

Oncocytomas, another benign renal mass, have no pathognomonic radiological appearance for RCC distinction. CT, USG, and MRI do not provide characteristic views of tumors. Therefore, most masses are diagnosed postoperatively (32). Paschal et al. found the mean ADC values of oncocytomas $(1.81 \pm 0.21)$ to be similar to clear cell RCC. It has been reported that this may be related to the size of ROI in the studies (33). Tauli et al. found that the mean ADC values of oncocytomas were quite high and significant $\left(1.91 \times 10^{-3} \mathrm{~mm}^{2} / \mathrm{s} \pm 0.97\right)$. This is important in the preoperative diagnosis of benign masses and may prevent unnecessary surgical interventions (28). In our study, the ADC values of the two oncocytoma cases $\left(1.76 \times 10^{-3} \mathrm{~mm}^{2} / \mathrm{s}\right)$ were higher than the RCCs. This gives us an important clue for the preoperative diagnosis of oncocytoma and the prevention of unnecessary surgical interventions. The small number of cases is our most significant limitation. However, the low frequency of oncocytomas compared to other tumors made the data obtained from these 2 cases valuable. When the mean ADCs of the angiomyolipomas together with oncocytoma were taken as a benign mass, it was found to be $1.38 \mathrm{x} \times 10^{-3}$ $\pm 0.31 \mathrm{~mm}^{2} / \mathrm{s}$, which gave a malignant mass image in the ADC data considered to be benign.

In our study, the fact that only one case was chromophobe cell RCC and could not be included in the statistical analysis, the exclusion of renal cysts with benign lesions, the small number of oncocytoma cases, and the unequal number of benign-malign lesions were 
the limitations of our study. Studies with more cases will provide more valuable information about the future use of DWI in renal masses.

Conclusion: DWI is an MRI technique that creates a contrast difference concerning the diffusion properties of water in vivo. Increased cellularity in malignant tissue causes diffusion restriction. ADC values can be a useful parameter to differentiate malignant lesions in renal masses. Also, significant differences in ADC values among RCC subtypes indicate the availability of ADC in RCC subtype determination.

\section{Funding Sources}

No funding was provided for this work

Conflicts of Interest

There is no conflict of interest in connection with this paper.

Acknowledgment

The authors thank all interviews for participating in the study. We thank Hulya Yerli for collecting our data.

\section{REFERENCES}

1. Volpe A, Panzarella T, Rendon RA, Haider MA, Kondylis FI, Jewett MA. The natural history of incidentally detected small renal masses. Cancer 2004;100:738-45.

2. Doehn C, Grünwald V, Steiner T, Follmann M, Rexer H, Krege S. The Diagnosis, Treatment, and Follow-up of Renal Cell Carcinoma. Dtsch Arztebl Int. 2016;113:590-6.

3. Hecht EM, Israel GM, Krinsky GA Hahn WY, Kim DC, Belitskaya-Levy I et al. Renal masses: Quantitative analysis of enhancement with signal intensity measurements versus qualitative analysis of enhancement with image subtraction for diagnosing malignancy at MR imaging. Radiology, 2004;232: 373-8.

4. Ozturk M, Ekinci A, Elbir SF, Okur A, Doğan S, Karahan ÖI. The usefulness of the apparent diffusion coefficient of diffusion-weighted imaging for differential diagnosis of primary solid and cystic renal masses. Polish J Radiol. 2017;82:209-15.

5. Alle N, Tan N, Huss J, Huang J, Pantuck A, Raman SS. Percutaneous image-guided core biopsy of solid renal masses: analysis of safety, efficacy, pathologic interpretation, and clinical significance. Abdom Radiol (NY). 2018;43(7):1813-9.

6. Maturen KE, Nghiem HV, Caoili EM, Higgins EG, Wolf JS Jr, Wood DP Jr. Renal mass core biopsy: accuracy and impact on clinical management. AJR 2007; 188:563-570: 8.

7. Herts BR, Baker ME. The current role of percutaneous biopsy in the evaluation of renal masses. Semin Urol Oncol. 1995:13:254-61.

8. Jemal A, Murray T, Ward E, Samuels A, Tiwari RC, Ghafoor A et al. Cancer statistics. Cancer J Clin. 2005;55:10-30.

9. Le Bihan D. Diffusion and perfusion magnetic resonance imaging. Mal Vasc. 1995;20:203-214.

10. Colagrande S, Carbone SF, Carusi LM, Cova M, Villari N. Magnetic resonance diffusion-weighted imaging: extraneurological applications. Radiol med. 2006;111:392-419.

11. Rosenkrantz AB, Oei M, Babb JS, Niver B, Taouli B. DWI of the abdomen at 3.0 Tesla: Image quality and ADC reprocibility compared with 1.5 Tesla. J Magn Reson Imaging. 2011;33:128-35.

12. Le Bihan D: Molecular diffusion nuclear magnetic resonance imaging. Magn Reson Q. 1991;7:1-30.

13. Schaefer PW, Grant PE, Gonzalez RG. Diffusion weighted MR imaging of the brain. Radiology. 2000;217:331-45.

14. Müller MF, Prasad PV, Bimmler D. Functional imaging of the kidney by means of measurement of the apparent diffusion coefficient. Radiology. 1994;193:711-5.

15. Taouli B, Beer AJ, Chenevert T, Collins D, Lehman C, Matos C et al. Diffusion-Weighted Imaging outside the brain: Consensus statement from an ISMRM-Sponsored Workshop. J Magn Reson Imaging. 2016;44(3):521-40.

16. Doğanay S, Kocakoç E, Çiçekçi M, Ağlamış S, Akpolat N, Orhan I. Ability and utility of diffusion-weighted MRI with different b values in the evaluation of benign and malign renal lesions. Clin Radiol. 2011;66:420-5.

17. Paudyal B, Paudyal P, Tsushima Y, Oriuchi N, Amanuma M, Miyazaki M et al. The role of the ADC value in the characterization of renal carcinoma by diffusion-weighted MRI. Br J Radiol. 2010;83:336-43.

18. Zhang JL, Sigmund EE, Chandarana H, Rusinek H, Chen Q, Vivier PH, et al. Variability of renal apparent diffusion coefficients: limitations of the monoexponential model for diffusion quantification. Radiology. 2010;254:783-92.

19. Rofsky NM, Bosniak MA. MR evaluation of small (<3cm) renal masses. MR Clin N Am 1997; 5:67-81.

20. Cova M, Squillaci E, Stacul F, Manenti G, Gava S, Simonetti G, et al. DWI in the evaluation of renal lesions: preliminary results. Br J Radiol 2004;77:851-7.

21. Fukuda Y, Ohashi I, Hanafusa K. Anisotropic diffusion in kidney apparent diffusion coefficient measurements for clinical use. J Magn Reson Imaging. 2000; 11:156-60.

22. Thoeny HC, Grenier N. Science to practice: Can diffusion-weighted MR imaging findings be used as biomarkers to monitor the progression of renal fibrosis? Radiology. 2010;255(3):667-8.

23. Togao O, Doi S, Kuro-o M, Masaki T, Yorioka N, Takahashi M. Assessment of renal fi brosis with diffusion-weighted MR imaging: study with murine model of unilateral ureteral obstruction. Radiology. 2010;255:772-80.

24. Wang H, Cheng L, Zhang X, Wang D, Guo A, Gao Y, et al. Renal Cell Carcinoma: Diffusion-weighted MR imaging for subtype differentiation at 3.0 T. Radiology. 2010;257:135-43.

25. Xu J, Does MD, Gore JC. Sensitivity of MR diffusion measurements to variations in intracellular structure: effects of nuclear size. Magn Reson Med. 2009;61:828-33.

26. Harkins KD, Galons JP, Secomb TW, Trouard TP. Assessment of the effects of cellular tissue properties on ADC measurements by numerical simulation of water diffusion. Magn Reson Med. 2009;62:1414-22.

27. Surov A, Meyer HJ, Wienke A. Correlation between apparent diffusion coefficient (ADC) and cellularity is different in several tumors: a meta-analysis. Oncotarget. 2017;8(35):59492-99. 
Phnx Med J. November, 2020. Volume 2 No 3

28. Taouli B, Thakur RK, Mannelli L, Babb JS, Kim S, Hecht EM, et al. Renal lesions: characterization with diffusion-weighted imaging versus contrast-enhanced MR imaging. Radiology. 2009;251:398-407.

29. Rosenkrantz AB, Niver BE, Fitzgerald FE, Babb JS, Chandarana H, Melamed J. Utility of the apparent diffusion coefficient for distinguishing clear cell renal cell carcinoma of low and high nuclear grade. AJR. 2010;195:344-51.

30. Sandrasegaran K, Sundaram CP, Ramaswamy R, Akişik F. Usefulness of DWI in the evaluation of renal masses. AJR. 2010;194:438-45.

31. Razek A, Farouk A, Mousa A, Nahil N. Role of Diffusion-Weighted magnetic resonance imaging for characterization of renal tumors. Journal Computer Assisted Tomography. 2011;35:332-6.

32. Rosenkrantz AB, Hindman N, Fitzgerald EF, Niver BE, Melamed J, Babb JS. MRI features of renal oncocytoma and chromophobe renal cell carcinoma. AJR. 2010;195:421-7.

33. Paschall AK, Mirmomen SM, Symons R, Pourmorteza A, Gautam R, Sahai A, et al. Differentiating papillary type I RCC from clear cell RCC and oncocytoma: application of whole-lesion volumetric ADC measurement. Abdom Radiol (NY). 2018;43(9):2424-30. 